\title{
Facilitating and Supporting EdD Students' Scholar Practitioner Writing as an Epistemological Tool
}

\author{
Carl I. Fertman, PhD, MBA, MCHES \\ University of Pittsburgh \\ carl@pitt.edu
}

\begin{abstract}
Becoming adept at crafting scholarly writing is an important aspect of a doctoral student's development. Presented in this article is an EdD course, embedded writing scaffold that engages students and faculty to develop students' scholarly inquiry projects. That scaffold is the Applied Inquiry Plan (AIP). The AIP creates a programmatic pathway to guide a Dissertation in Practice. Working to improve the quality and value of scholar practitioner writing parallels and draws from efforts in the biomedical fields to develop writing guidelines that impact the quality and value of practice. Creating and using the AIP provides opportunities for broad discussion of how to engage EdD students to view their writing as an epistemological tool. Discussed is the AIP impact on EdD program redesign and improvement.
\end{abstract}

KEYWORDS: writing, writing scaffolds, EdD students, scholar practitioner, Dissertation in Practice

\section{INTRODUCTION}

Writing has enormous relevance to the way EdD programs construct themselves to develop scholar practitioners who create practitioner inquiry agendas, build professional visibility, and produce practice based knowledge, products, and services (Carnegie Project on the Education Doctorate [CPED], 2010). The goal for the written work of EdD students can be framed around CPED's principles. That is, it be original, significant, and framed around questions of equity, ethics, and social justice. Furthermore, that the written work help to bring about solutions to complex problems of practice and prepare leaders who can construct and apply knowledge to make a positive difference in the lives of individuals, families, organizations, and communities. Finally, EdD students' written works should emphasize the generation, transformation, and use of professional knowledge and practice (CPED, 2010).

One of the instructional EdD teams I teach with at the University of Pittsburgh uses writing scaffolds to allow students to understand the features of a number of scholar practitioner genres, see a model of a written text in the genres, participate in the creation of texts in the genres, and independently write text in the genres. We promote the concept of scholarly practitioner genres aligned with Wolfberg and Lyytinen's (2017) model of scholar practitioner writing genres that spans between academia and practice. We examine empirical papers, typically academic journal articles with dedicated practice sections, that communicate significant empirical findings of practical and theoretical importance with a demonstrated influence on practice. These are grounded on reporting findings of empirical inquiry to a problem of practice and the inquiry are founded on qualitative, quantitative, or mixed methods. In these papers we appraise how the authors position their inquiry within the literature, briefly and accurately describe the methods used, condense the empirical and theoretical findings, and discuss clearly the lessons for practice. We review foundation, governmental, and nongovernmental independent organization publications and reports of practice successes, challenges, and future directions to impact practice. We study national and state level professional products from organization and conference trainings and presentations, to provide directions and guidance on how to approach and influence specific practices, focusing on one or more select theories to discuss how the chosen theories inform the formulation and address a specific problem of practice. Finally we analyze practitioner journals practice materials and dissertations for the nature of scholar practitioner knowledge, related epistemologies, methods of inquiry, and their relationships to practice or forms of knowing in practice. Across the genres we seek writing with language widely understood in everyday practice. We place priority on narrating the tangible context and the lived experience of stakeholders, and look to see if it is oriented toward concrete solutions and actions whereby real-world problems are resolved. This voice is persuasive, and reports lived experience and specific narrative forms to examine the context and goals of the proposed action (Wolfberg \& Lyytienen, 2017).

\section{Writing Scaffolds}

Our use of writing scaffolds parallels efforts in the biomedical fields that develop writing guidelines. In particular, we model our work on the SQUIRE (Standards for Quality Improvement Reporting Excellence) guidelines intended as a guide for authors reporting on systematic, data-driven efforts to improve the quality, safety and value of healthcare (Goodman et al., 2016; Ogrinc et al., 2008). SQUIRE was designed to increase the completeness and transparency of reporting of quality improvement work, and since its publication in 2008, has contributed to the development of this body of literature by providing a guide to authors, editors, reviewers, educators and other stakeholders. We also use the TIDieR
New articles in this journal are licensed under a Creative Commons Attribution 4.0 United States License.

This journal is published by the University Library System of the University of Pittsburgh as part of its D-Scribe Digital Publishing Program and is cosponsored by the University of Pittsburgh Press.

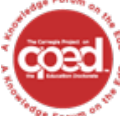

This journal is supported by the Carnegie Project on the Education Doctorate: A Knowledge Forum on the EdD (CPED) cpedinitiative.org

impactinged.pitt.edu

Vol. 3, No. 2 (2018)
ISSN 2472-5889 (online) DOI $10.5195 /$ ie. 2018.87 
guidelines-Template for Intervention Description and Replication Checklist and Guide (Hoffmann et al., 2014)—because it is a model for how to provide quality descriptions of interventions.

The reason we modeled our work on the SQUIRE and TIDieR guidelines is they provide a framework for reporting new knowledge on how to improve practice and replicate improvement efforts. They can be used across the scholarly practitioner genres. The SQUIRE Explanation and Elaboration documents (Goodman et al., 2016) provide specific models of scaffold structures and documentation. Likewise the clear and concise writing grounded in practice modeled by SQUIRE and TIDieR guidelines is consistent with Wolfberg and Lyytienen's (2017) efforts to define scholar practitioner writing genres.

Finally, scaffolding is based on social learning theory (Bandura, $1995)$ to support students' transition from assisted tasks to independent performance (Bliss \& Askew, 1996). It is a step-by-step process that provides the learner with sufficient guidance until the process is learned, and then gradually removes the supports in order to transfer the responsibility for completing the task to the student. In particular, we have found that it is a balancing act to provide EdD students with the optimal amount of support necessary to write in varied scholar practitioner genres and to appreciate and understand the iterative writing process of drafting, soliciting feedback, editing, and revising (Menter, Elliot, MHulme, Lewin, \& Lowden, 2011).

Establishing writing scaffolding as part of an EdD program infrastructure can start with the first class. For example, we start with students first reading and familiarizing themselves with the varied scholar practitioner genres all the way to structured writing assignments with prompts, word counts, and expected number of primary source references. Faculty feedback is also scaffolded with forms, rubrics, and directions to guide and shape faculty feedback so students (as well as faculty) know the intention of the audience and measure of how well the writing matches the intention (Graff \& Birkenstein, 2014).

\section{Applied Inquiry Plan (AIP)}

In our Practitioner Inquiry course series we have developed an AIP_Applied Inquiry Plan (Figure 1)—to develop EdD students' Dissertation in Practice. The AIP creates a programmatic pathway to guide a dissertation in practice (and depending on a department's scholarly inquiry project could be a guide to a dissertation, capstone, or demonstration of professional practice). The AIP intention is to guide scholar practitioner inquiry reporting on systematic, data-driven (qualitative, quantitative and mixed methods) efforts to improve the quality and value of practitioner scholar inquiry as well as to provide quality descriptions of the inquiry. It is a practical guide, a "why to" and "how to" to help clarify a student's problem of practice and the details of the inquiry. It is a plan for the student's evolving inquiry. It is a discussion document for the student and faculty (e.g. advisor) to plan for, and adjust, aspects and details of the student's inquiry. Each sequential AIP item was written collaboratively by the instructional team members representing disciplines and professional backgrounds across our EdD program eight areas of concentration (ARCOs), reflecting a wide range of knowledge and experience. Similar to the SQUIRE Explanation and Elaboration document (Goodman et al., 2016; Ogrinc et al., 2008) for each item there is a brief description. Furthermore the AIP draws from the TIDieR guidelines-Template for Intervention Description and Replication Checklist and Guide (Hoffmann et al., 2014)—to provide quality descriptions of interventions. Without a complete, concise description of the inquiry, practitioners, stakeholders, consumers, and other decision makers cannot replicate or build on inquiry findings. The AIP's items focus is broader, beyond the specifics of an intervention. Therefore, AIP items detail a deliverable with a suggested content and length (e.g. page and word counts).

The writing scaffold breaks the AIP into three supported and discussed assignments (Assignments A, B, C). It is an iterative, evolving document. Students complete an assignment and receive peer and course instructors' feedback after which students meet with their advisors for further refinement and revision while starting to work on the next assignment. This sequence continues through the three assignments that build upon each other culminating in the finished AIP. The students are responsible to schedule three meeting dates (in person, phone, skype, etc.) that are documented through an advisor sign-off (Figure 2). This is not just a formality-it is designed to make sure a student and advisor are on the same page regarding the student's inquiry plan.

The AIP is evaluated via a rubric that the course instructors use. Each assignment focuses on specific parts of the AIP with various points and weights (Figure 3). However, most critical is feedback from the advisors. The evaluation rubric is focused on thoroughness, specificity, and appropriateness of information and completion of the assignment, as detailed. The content feedback from the advisor is most focused on the inquiry itself. To prepare students for their discussions of their AIPs with the advisors as part of each assignment, students prepare questions and concerns to use during the discussions with the advisors. As part of class, we use role plays to support students to be assertive in how they raise questions and concerns related to their inquiry. Our evaluation rubric also includes points for the advisor questions and concerns. At times, students receive conflicting and contradicting feedback and comments. This is grist for discussion with peers, course instructors, and advisors as part of the students' decision making related to their inquiry plan.

The AIP is completed in the third Practitioner Inquiry course, however, it is not the first or last time students interact with it. Rather from the first course in the four-course Practitioner Inquiry series to the fourth course, students are discussing, drafting, and revising AIP sections. It becomes a living document going through iterations leading to the dissertation in practice. The AIP aligns with and support the CPED principle that defines a dissertation in practice as one that exhibits the doctoral candidate's ability to think, to perform, and to act with integrity, addresses the development of scholarly practitioners who are consumers of research, identifies scholarly practitioners as those who merge practical knowledge with professional skills to solve problems of practice, and practitioners use scholarly research to apply theory to practice in an effort to achieve educational change(CPED, 2010).

\section{AIP Impact on Program Redesign and Improvement}

Beyond being a guide and support to scholar practitioner writing, the AIP is a vehicle to engage and support EdD students to view their writing as an epistemological tool. Central to our argument for the development and use of the AIP process is it fosters not only scholarly writing, but a student's ability to write seeking equity, ethical actions, and social justice, to bring about solutions to complex problems of practice, and to prepare leaders who can construct and apply knowledge to make a positive 


\begin{tabular}{|c|c|c|c|c|}
\hline & SECTION & DESCRIPTION & DELIVERABLE & $\begin{array}{l}\text { DEADLINES and } \\
\text { APPROVALS }\end{array}$ \\
\hline 1 & PROBLEM AREA & $\begin{array}{l}\text { Problem of Practice context and background. As you have learned, as } \\
\text { you frame a problem for consideration as a leader, you must consider } \\
\text { the fuller context of that problem: How has the problem area been } \\
\text { described and explored by other inquiries? What frames the problem } \\
\text { more widely? }\end{array}$ & $\begin{array}{l}\text { Provide a focused summary of the broader area of } \\
\text { professional practice from which your Problem or } \\
\text { Practice emanates. }\left(1 \text { page }^{1} \text { ) }\right.\end{array}$ & $\begin{array}{l}\text { 1/27/18 } \\
\text { Instructor, } \\
\text { Assignment A } \\
\text { 2/24/18 } \\
\text { Advisor sign-off }\end{array}$ \\
\hline 2 & INQUIRY SETTING & $\begin{array}{l}\text { What is the practice-related setting for the inquiry? How does the } \\
\text { setting inform and constrain both the problem and the ways in which it } \\
\text { can be explored? }\end{array}$ & $\begin{array}{l}\text { Provide a detailed description of the specific site or } \\
\text { organization with a focus on key characteristics that } \\
\text { are central to the problem. ( } 1 / 2 \text { page })\end{array}$ & $\begin{array}{l}\text { 1/27/18 } \\
\text { Instructor, } \\
\text { Assignment A } \\
\text { 2/24/18 } \\
\text { Advisor sign-off }\end{array}$ \\
\hline 3 & STAKEHOLDERS & $\begin{array}{l}\text { Who are the various people (or groups of people) who have a "stake" in } \\
\text { the context and issues of the problem, both directly and indirectly? }\end{array}$ & $\begin{array}{l}\text { Provide a detailed description of the specific } \\
\text { individuals, or group of individuals and stakeholders } \\
\text { demographics and key characteristics that are } \\
\text { central to the problem. ( } 1 / 2 \text { page) }\end{array}$ & $\begin{array}{l}\text { 1/27/18 } \\
\text { Instructor, } \\
\text { Assignment A } \\
\text { 2/24/18 } \\
\text { Advisor sign-off }\end{array}$ \\
\hline 4 & $\begin{array}{l}\text { PROBLEM OF } \\
\text { PRACTICE }\end{array}$ & $\begin{array}{l}\text { What is your Problem of Practice and how does it manifest in this } \\
\text { specific setting, with these specific stakeholders? }\end{array}$ & $\begin{array}{l}\text { Provide a focused description of Problem of Practice } \\
\text { that is situated by the PROBLEM AREA, in this } \\
\text { INQUIRY SETTING and among these } \\
\text { STAKEHOLDERS. (1 page) }\end{array}$ & $\begin{array}{l}\text { 1/27/18 } \\
\text { Instructor, } \\
\text { Assignment A } \\
\text { 2/24/18 } \\
\text { Advisor sign-off }\end{array}$ \\
\hline 5 & INQUIRY QUESTIONS & $\begin{array}{l}\text { What are the specific questions that will guide the study of this Problem } \\
\text { of Practice? }\end{array}$ & $\begin{array}{l}\text { Enumerate the specific QUESTIONS to explore and } \\
\text { address in the inquiry. ( } 3-5 \text { focused questions, } 1 \\
\text { page) }\end{array}$ & $\begin{array}{l}\text { 2/24/18 } \\
\text { Instructor, } \\
\text { Assignment B } \\
\text { 3/31/18 } \\
\text { Advisor sign-off }\end{array}$ \\
\hline 6 & INQUIRY DESIGN & $\begin{array}{l}\text { What is your inquiry design (e.g. improvement science, evaluation, } \\
\text { action research ....) for your Problem of Practice inquiry? }\end{array}$ & $\begin{array}{l}\text { Provide a focused summary of the INQUIRY } \\
\text { DESIGN you anticipate will frame this inquiry. ( } 1 / 2 \\
\text { page) }\end{array}$ & $\begin{array}{l}\text { 2/24/18 } \\
\text { Instructor, } \\
\text { Assignment B } \\
\text { 3/31/18 } \\
\text { Advisor sign-off }\end{array}$ \\
\hline 7 & $\begin{array}{l}\text { EVIDENCE AND } \\
\text { METHOD }\end{array}$ & $\begin{array}{l}\text { What evidence will be collected; how will it be collected (methods) and } \\
\text { how does the evidence and methods align with the inquiry questions? }\end{array}$ & $\begin{array}{l}\text { Provide a chart that details the alignment of } \\
\text { INQUIRY QUESTIONS, EVIDENCE, and } \\
\text { METHODS you will use to gather the evidence. } \\
\text { (One chart row for each Inquiry Question, } 2 \text { pages) }\end{array}$ & $\begin{array}{l}\text { 2/24/18 } \\
\text { Instructor, } \\
\text { Assignment B } \\
\text { 3/31/18 } \\
\text { Advisor sign-off }\end{array}$ \\
\hline 8 & $\begin{array}{l}\text { ANALYSIS AND } \\
\text { INTERPRETATION }\end{array}$ & $\begin{array}{l}\text { How will the evidence be examined, considered in terms of the } \\
\text { literature of the field, and situated in the context of practice? }\end{array}$ & $\begin{array}{l}\text { Add a column to the chart produced in Step } 7 \text { to } \\
\text { detail the types of ANALYSES planned to further } \\
\text { EXAMINE and INTERPRET the evidence. (One } \\
\text { additional column in the chart) }\end{array}$ & $\begin{array}{l}\text { 3/31/18 } \\
\text { Instructor, } \\
\text { Assignment C } \\
\text { 4/20/18 } \\
\text { Advisor sign-off }\end{array}$ \\
\hline 9 & $\begin{array}{l}\text { PROPOSED } \\
\text { DELIVERABLE } \\
\text { PRODUCT }\end{array}$ & $\begin{array}{l}\text { What is the planned product of the Dissertations of Practice and how do } \\
\text { you anticipate its use? }\end{array}$ & $\begin{array}{l}\text { Provide a description of what you anticipate as the } \\
\text { PRODUCT of the inquiry and how it may be used to } \\
\text { inform practice and/or influence policy. (1 page) }\end{array}$ & $\begin{array}{l}\text { 3/31/18 } \\
\text { Instructor, } \\
\text { Assignment C }\end{array}$ \\
\hline
\end{tabular}

${ }^{1}$ Length of each section is suggested only to provide some guidance 


\begin{tabular}{|c|c|c|c|c|}
\hline & SECTION & DESCRIPTION & DELIVERABLE & $\begin{array}{l}\text { DEADLINES and } \\
\text { APPROVALS }\end{array}$ \\
\hline & & & & $\begin{array}{l}\text { 4/20/18 } \\
\text { Advisor sign-off }\end{array}$ \\
\hline 10 & PROPOSED TIMELINE & $\begin{array}{l}\text { What is the proposed timeline for major steps of your inquiry and the } \\
\text { Dissertation of Practice that is feasible within reasonable confines of } \\
\text { your degree? }\end{array}$ & $\begin{array}{l}\text { Produce an estimated timeline or Gantt chart to } \\
\text { match your inquiry. ( } 1 \text { page timeline/chart) }\end{array}$ & $\begin{array}{l}\text { 3/31/18 } \\
\text { Instructor, } \\
\text { Assignment C } \\
\text { 4/20/18 } \\
\text { Advisor sign-off }\end{array}$ \\
\hline
\end{tabular}

\section{Assignment Flow, Assumptions, and Point Values:}

EDUC 3009 Product - The completed in the fall term EDUC 3009 product will be a course resource as well as a platform for the work of EDUC 3007 . Document upload is due January 11, 2018. The assignment is worth 5 points and is graded as uploaded.

Assignment A: (approximately 3 pages): Assignment consist of a revision and reworking of materials that students have already completed in Practitioner Inquiry 1 and 2 and Review of Supporting Literature completed with Advisor. It will be handed in ONE WEEK prior to class time (January 27, 2018), allowing for instructor feedback and peer work in class on February 3 , 2018. After instructor and class review, students must make arrangements for their advisors to review/comment/sign off on this assignment. As part of the assignment students prepare questions and identify concerns to discuss with their advisors. Sign-off document is due February 24,2018 . This assignment is worth 20 points and graded with a rubric.

Assignment B: (approximately $3 \frac{1}{2}$ pages) This assignment follows a similar trajectory (individual drafting, hand in for instructor review and comment February 24,2018 , time for in class review on March 3, 2018, followed by an additional month for advisor review/comment sign off by March 31, 2018. As part of the assignment students prepare questions and identify concerns to discuss with their advisors. This assignment is worth 20 points and graded with a rubric.

Assignment C: (approximately 4 pages) This assignment follows a similar trajectory (individual drafting, hand in for instructor review and comment March 31,2018 , time for in class review on April 7, 2018 with advisor review/comment sign off by April 20, 2018. As part of the assignment students prepare questions and identify concerns to discuss with their advisors. This assignment is worth 20 points and graded with a rubric.

MODULE ASSIGNMENTS: Similar to how online activities were scheduled in Practitioner Inquiry 2, additional module-associated assignments graded with a rubric. The modules will award up to 35 points toward the final grade.

The total points for the course (100) will be divided by Assignments A, B, and C (60 points) which comprises the Applied Inquiry Plan, 5 points for the EDUC 3009 Product upload and 35 points for Module assignments.

Figure 1. Applied Inquiry Plan Guiding the Dissertation of Practice.

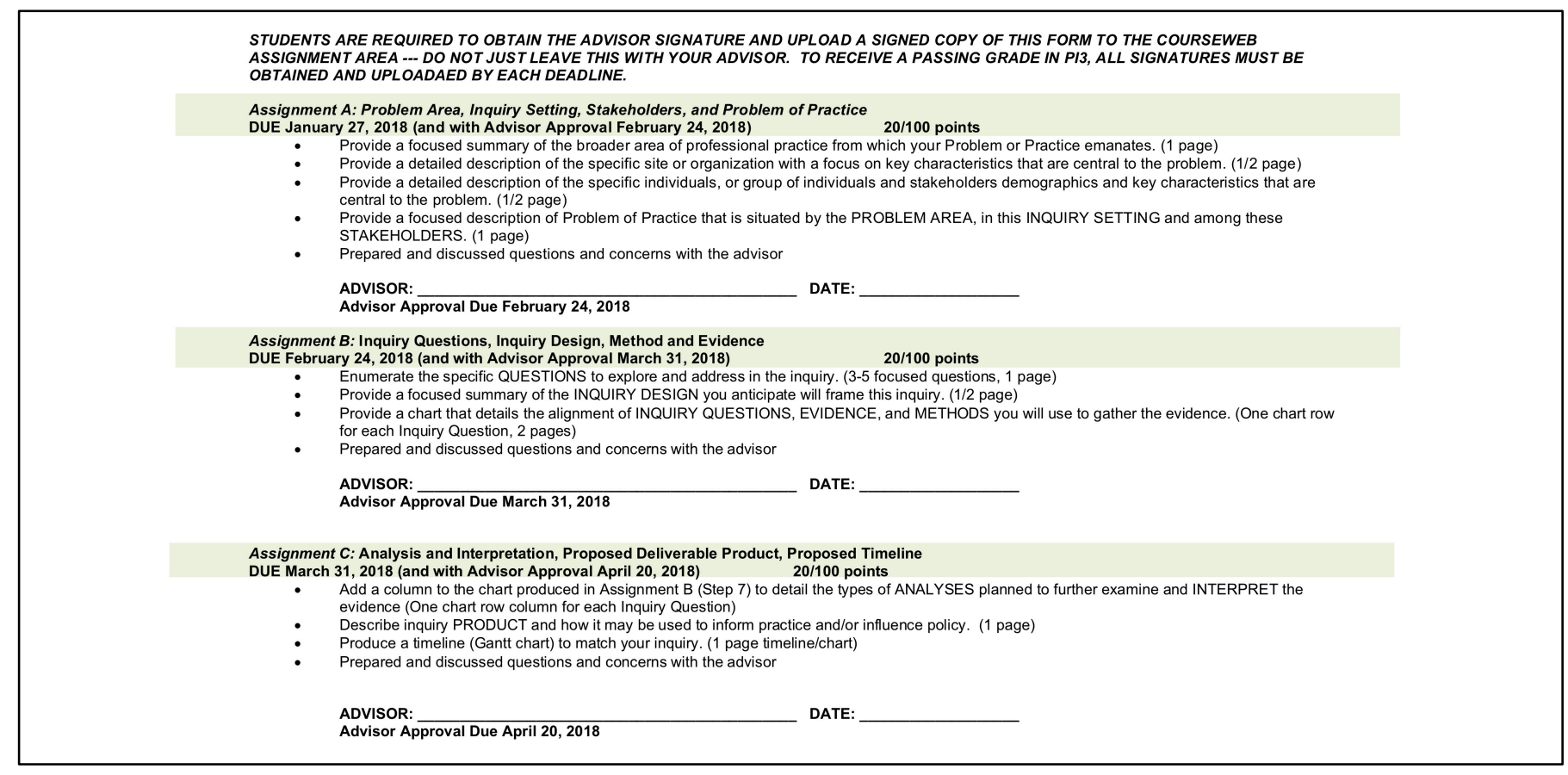

Figure 2. Practitioner Inquiry 3: Applied Inquiry Plan Assignments Advisor Sign Off Sheet. 
difference in the lives of individuals, families, organizations, and communities. This discussion within an EdD program is not dependent on using the AIP or any other course embedded writing scaffold. Rather for us the AIP provided the pathway for such conversation to elevate and deepen students' thinking about their writing and its potential as a tool to create new knowledge and impact practice. The AIP impact on our program redesign and improvement is fourfold.

First, it impacted the process to elevate and deepen students' thinking about how their writing can create new knowledge and impact practice. In working with students on their AIPs, we have found we need to do more than help students to increase their productivity (e.g. "write more") or help them to be "better" at writing, particularly if our goal is for them to create new knowledge and impact practice. We concluded that we needed to ask the questions: do students really see themselves as writers?; and, would seeing themselves as writers help them reframe writing not as a task (e.g. completing the AIP) but a tool in their work to create new knowledge and impact practice? In the process of answering these questions, we became aware that much of the encouragement of students to write focuses on embodying different behaviors (e.g. get up early, write every day, write simple).

Following a model of Banks and Flinchbaugh (2013) based on a rhetorical refiguration of writerly identity, we talk with students about why they do or do not see themselves as writers and have students embody a new writerly ethos. However rather than a dichotomous decision of simply being a writer or not being a writer, students are approached in ways that encourage them to adopt writer as one of their ethos or roles or identities (Castells, 1996). As students begin to adopt this ethos, they make the move from students and practitioners who write as part of their course work and jobs toward writer-practitioners and, eventually as they progress through the program, to writer-scholar-practitioners who can embrace themselves as writers.

\section{Second, we had to consider how to engender} student commitment to writing to create new knowledge and impact practice. We do not believe any single project, activity, or class assignment can effect students' commitment to write. By working with students to refigure their relationship to writing and embracing that change as a programmatic goal that weaves through our courses, we believe we have a better chance of meeting student writers where they are. This allows students to begin to experience themselves as writers in divergent contents. For if writing is the meta-discipline as Murphy et al. (2009) has argued, we should engage writing and writers as frequently and flexibly as possible, taking each opportunity we have to help students see themselves as writers. The AIP spanning our EdD courses facilitates this process. It is woven into course assignments and referenced during discussions with AIP section exemplars shared to have students reflect on their own writing.

Faculty feedback and input play a role in students' commitment to writing. We know students want faculty feedback and input on their writing. An important aspect of constructing the AIP was attention to how we engender student commitment to writing and provide students with feedback. An important consideration therefore in the AIP design and assignment configuration was Practitioner Inquiry course instructors, student peers, and EdD advisors all reading AIP assignments (e.g. Assignments A, B, C). To accomplish this goal, AIP items are concise and focused to facilitate students receiving both technical and content feedback as well as suggestions for revisions and next draft. Course instructors and student peers focus on AIP section requirements (e.g. word counts, number of references, school style guidelines) as well as content. Feedback from peers is structured into the courses' process with designated times and procedures. Advisors are the content experts and ultimate decision makers for students' inquiries and AIP content. We team teach the Practitioner Inquiry courses. Course instructors share their feedback to students with co-instructors as well as advisors and likewise. As stated earlier, the feedback may conflict. It is thereby grist for the student and advisor discussions.

The feedback and engaging students in discussions of their inquiry results in the AIP being understood by students and faculty as a living document that is refined and revised through iteration and drafting. Students become part of a community of writers in which their writing is read and valued. Students experience themselves as writers in divergent contents as they begin to grasp what it means to create new knowledge and impact practice through writing.

Third, we had to consider students could have interest in exploring a problem of practice that does not necessarily have a clear and direct link to impacting practice and creating new knowledge. It is not unusual for students to view their inquiry as important but be less clear on how it will impact practice or create new knowledge. Likewise, links to social justice, community, and organizations may also be unclear to the students. Undoubtedly, they will agree that these are worthwhile and important but they may not feel strongly about them and view them as distal to their inquiry.

For these students the AIP process is how the students develop passion and emotion in their writing. What we strive for with these students is that their writing as scholar practitioners take on meaning and urgency. Working with students on the AIP, students ground and develop sound arguments (points of view) and synthesize and respond to other people's work. Furthermore, in producing the AIP, students interact with the communities and organizations of which they are members and various stakeholders, for it is only within these communities and organizations as insiders do they construct meaning. Only in relation to these communities and organizations are meanings validated, and they only receive validation to the extent they are compatible with the understandings and practice of the communities and organizations (Hyland, 2004). What often happens is a clash between the academic program and AIP demands for conformity in writing and stakeholders' need for information on how to impact practice in the communities and organizations. As part of the AIP student and faculty discussions, students wrestle with, and perhaps accept, the ambiguity presented by these positions, or at least hold them both in their hearts and hands as fuel for writing. It stokes a personal writing agenda, identifying likeminded colleagues, communities, organizations, and outlets for one's writing. The process for faculty and students is creative and imaginative. It provides students access to their personal passion and intention, often motivation for delving deeper into the literature and critical inquiry in search for answers to address individual, community, and organizational needs. 


\begin{tabular}{|c|c|c|c|c|}
\hline & INADEQUATE & NEEDS IMPROVEMENT & SATISFACTORY & WELL EXECUTED \\
\hline $\begin{array}{l}\text { Problem Area } \\
\text { The problem area is framed for broad } \\
\text { understanding of the issue. } \\
\text { Frame will include: } \\
\text { professional context \& background: how is this } \\
\text { area described in professional practice? } \\
\text { scholarly context \& background: what do other } \\
\text { inquiries and the literature tell you about this } \\
\text { area? }\end{array}$ & $\begin{array}{l}\text { Problem of } \\
\text { practice is not } \\
\text { adequately } \\
\text { described. }\end{array}$ & $\begin{array}{l}\text { Some understanding of problem } \\
\text { area is given; not clearly situated } \\
\text { in professional and scholarly } \\
\text { background \& context. }\end{array}$ & $\begin{array}{l}\text { Adequate understanding of } \\
\text { problem as it is situated in } \\
\text { professional and scholarly } \\
\text { background \& context }\end{array}$ & $\begin{array}{l}\text { Understanding of problem is fully } \\
\text { situated in professional and } \\
\text { scholarly background and context } \\
\text { with well developed examples and } \\
\text { evidence. }\end{array}$ \\
\hline $\begin{array}{l}\text { Inquiry Setting } \\
\text { Provide a detailed description of the specific } \\
\text { site/organization. Details will include: } \\
\text { Key characteristics that are central to the problem } \\
\text { area. } \\
\text { Description of how the setting informs problem } \\
\text { Description of how the setting constrains problem } \\
\text { Ways in which the problem can be explored. }\end{array}$ & $\begin{array}{l}\text { Inquiry setting } \\
\text { is not } \\
\text { adequately } \\
\text { described }\end{array}$ & $\begin{array}{l}\text { Some description of setting and } \\
\text { how it informs, constrains and will } \\
\text { guide exploration of problem but } \\
\text { details are lacking. }\end{array}$ & $\begin{array}{l}\text { Adequate understanding of the } \\
\text { setting and how it informs, } \\
\text { constrains and will guide } \\
\text { exploration of problem. }\end{array}$ & $\begin{array}{l}\text { Strong understanding of the role of } \\
\text { setting in relation to the problem } \\
\text { area \& how it informs, constrains } \\
\text { and will guide exploration of } \\
\text { problem is demonstrated with } \\
\text { examples and evidence }\end{array}$ \\
\hline $\begin{array}{l}\text { Stakeholders } \\
\text { Provide a detailed description of the specific } \\
\text { individuals, or group of individuals and } \\
\text { stakeholders including: } \\
\text { demographics } \\
\text { key characteristics } \\
\text { how each of these are central to the problem } \\
\text { description of their "stake" in this problem directly } \\
\text { and/or indirectly. }\end{array}$ & $\begin{array}{l}\text { Stakeholders } \\
\text { not adequately } \\
\text { described. }\end{array}$ & $\begin{array}{l}\text { Some description of stakeholders } \\
\text { and their characteristics, } \\
\text { demographics and "stake", but } \\
\text { not convincing or clear. }\end{array}$ & $\begin{array}{l}\text { Adequate description of } \\
\text { stakeholders and their } \\
\text { characteristics, demographics } \\
\text { and "stake" }\end{array}$ & $\begin{array}{l}\text { Clear description of stakeholders } \\
\text { and their characteristics, } \\
\text { demographics and "stake" } \\
\text { demonstrated with examples and } \\
\text { evidence. }\end{array}$ \\
\hline $\begin{array}{l}\text { Problem of Practice } \\
\text { Provide a focused description of Problem of } \\
\text { Practice that is situated by the: } \\
\text { Problem area } \\
\text { Inquiry setting } \\
\text { Stakeholders } \\
\text { Provide clear understanding of how the problem } \\
\text { of practice is manifested in these three } \\
\text { components. }\end{array}$ & $\begin{array}{l}\text { Problem of } \\
\text { practice is not } \\
\text { adequately } \\
\text { described. }\end{array}$ & $\begin{array}{l}\text { Some description of problem of } \\
\text { practice but it is not focused by } \\
\text { the problem area, inquiry setting } \\
\text { and/or stakeholders; Limited } \\
\text { understanding of how problem of } \\
\text { practice manifests in these three. }\end{array}$ & $\begin{array}{l}\text { Adequate description of problem } \\
\text { of practice situated in the problem } \\
\text { area, inquiry setting and/or } \\
\text { stakeholders; Adequate } \\
\text { understanding of how problem of } \\
\text { practice manifests in these three. }\end{array}$ & $\begin{array}{l}\text { Clear description of problem of } \\
\text { practice situated in the problem } \\
\text { area, inquiry setting and/or } \\
\text { stakeholders; Strong understanding } \\
\text { of how problem of practice } \\
\text { manifests in these three as } \\
\text { demonstrated with examples and } \\
\text { evidence. }\end{array}$ \\
\hline $\begin{array}{l}\text { Inquiry Questions } \\
\text { Enumerate the specific questions that will: } \\
\text { Explore } \\
\text { Address } \\
\text { your problem of practice through a formal study. }\end{array}$ & $\begin{array}{l}\text { Inquiry } \\
\text { questions are } \\
\text { not adequately } \\
\text { written. }\end{array}$ & $\begin{array}{l}\text { Some questions written but not } \\
\text { with clear intention of exploring or } \\
\text { addressing the problem of } \\
\text { practice in a formal study }\end{array}$ & $\begin{array}{l}\text { Adequate list of questions written } \\
\text { with clear intention of exploring or } \\
\text { addressing the problem of } \\
\text { practice in a formal study. }\end{array}$ & $\begin{array}{l}\text { Clear list of questions written with } \\
\text { clear intention of exploring or } \\
\text { addressing the problem of practice } \\
\text { in a formal study. }\end{array}$ \\
\hline $\begin{array}{l}\text { Inquiry Design } \\
\text { What is your inquiry design (e.g. improvement } \\
\text { science, evaluation, action research ....) for your } \\
\text { Problem of Practice inquiry? }\end{array}$ & $\begin{array}{l}\text { Inquiry design } \\
\text { is not } \\
\text { adequately } \\
\text { described. }\end{array}$ & $\begin{array}{l}\text { Some description of the inquiry } \\
\text { design but purpose is not clear. }\end{array}$ & $\begin{array}{l}\text { Adequate description of inquiry } \\
\text { design with purpose clearly } \\
\text { defined. }\end{array}$ & $\begin{array}{l}\text { Strong description of inquiry design } \\
\text { with purpose clearly defined and } \\
\text { rationale for the choice of this } \\
\text { design. }\end{array}$ \\
\hline $\begin{array}{l}\text { Evidence and Method } \\
\text { In a detailed chart, describe the methods used to } \\
\text { collect evidence } \\
\text { What evidence will be collected; } \\
\text { How evidence aligns with the inquiry questions }\end{array}$ & $\begin{array}{l}\text { Evidence and } \\
\text { method not } \\
\text { clearly } \\
\text { described. }\end{array}$ & $\begin{array}{l}\text { Some description of evidence and } \\
\text { method provided but format not } \\
\text { clear, connections not clear. }\end{array}$ & $\begin{array}{l}\text { Adequate description of evidence } \\
\text { and method with clear chart and } \\
\text { details. }\end{array}$ & $\begin{array}{l}\text { Clear and strong description of } \\
\text { evidence and method with clear } \\
\text { chart and details that show strong } \\
\text { connections between method and } \\
\text { inquiry questions. }\end{array}$ \\
\hline $\begin{array}{l}\text { Analysis \& Interpretation } \\
\text { Detailed description the types of analysis } \\
\text { planned: } \\
\text { How analysis will further examine and interpret } \\
\text { the evidence. } \\
\text { Relate type of analysis to literature in the field. }\end{array}$ & $\begin{array}{l}\text { Analysis and } \\
\text { interpretation } \\
\text { not clearly } \\
\text { described. }\end{array}$ & $\begin{array}{l}\text { Some description of analysis and } \\
\text { interpretation but connections not } \\
\text { clear and not related to field } \\
\text { literature. }\end{array}$ & $\begin{array}{l}\text { Adequate description of analysis } \\
\text { and interpretation with } \\
\text { understanding of how analysis will } \\
\text { examine \& interpret evidence; } \\
\text { related to literature }\end{array}$ & $\begin{array}{l}\text { Description of analysis and } \\
\text { interpretation with strong } \\
\text { understanding of how analysis will } \\
\text { examine \& interpret evidence; clear } \\
\text { relation to literature }\end{array}$ \\
\hline
\end{tabular}




\begin{tabular}{|c|c|c|c|c|}
\hline & INADEQUATE & NEEDS IMPROVEMENT & SATISFACTORY & WELL EXECUTED \\
\hline $\begin{array}{l}\text { Proposed Deliverable Product } \\
\text { Provide a description of: } \\
\text { The product of the inquiry } \\
\text { How it may be used to inform practice and/or } \\
\text { influence policy }\end{array}$ & $\begin{array}{l}\text { Deliverable } \\
\text { product not } \\
\text { described }\end{array}$ & $\begin{array}{l}\text { Some description of deliverable } \\
\text { product and use in practice but } \\
\text { not clear or convincing. }\end{array}$ & $\begin{array}{l}\text { Adequate description of } \\
\text { deliverable product and use in } \\
\text { practice. }\end{array}$ & $\begin{array}{l}\text { Strong and clear description of } \\
\text { deliverable product and use in } \\
\text { practice supported by examples } \\
\text { and details. }\end{array}$ \\
\hline $\begin{array}{l}\text { Proposed Timeline } \\
\text { Produce timeline or Gantt chart that: } \\
\text { Matches your inquiry } \\
\text { Outlines action major steps } \\
\text { Is reasonable within the confines of your degree }\end{array}$ & $\begin{array}{l}\text { Timeline is not } \\
\text { provided. }\end{array}$ & $\begin{array}{l}\text { Minimal timeline provided; details } \\
\text { lacking. }\end{array}$ & $\begin{array}{l}\text { Adequate and clear timelines } \\
\text { provided; clear match to inquiry; } \\
\text { outlines major steps; is } \\
\text { reasonable for completion in } \\
\text { given timeframe. }\end{array}$ & $\begin{array}{l}\text { Clear and detailed timelines with } \\
\text { detailed major steps provided. } \\
\text { Strong match to inquiry and clear } \\
\text { indication that work is doable in } \\
\text { degree timeframe. }\end{array}$ \\
\hline $\begin{array}{l}\text { Advisor Questions and Concerns } \\
\text { As part of each assignment iteration students } \\
\text { prepare questions and identify concerns to } \\
\text { discuss with their advisors }\end{array}$ & $\begin{array}{l}\text { Advisor } \\
\text { questions and } \\
\text { concerns to } \\
\text { discuss are } \\
\text { not adequately } \\
\text { written. }\end{array}$ & $\begin{array}{l}\text { Some questions and concerns to } \\
\text { discuss but not with clear } \\
\text { intention of exploring or } \\
\text { addressing them in the AIP } \\
\text { development. }\end{array}$ & $\begin{array}{l}\text { Adequate list of questions and } \\
\text { concerns to discuss with clear } \\
\text { intention of exploring or } \\
\text { addressing them in the AIP } \\
\text { development. }\end{array}$ & $\begin{array}{l}\text { Clear list of questions and concerns } \\
\text { with clear intention of exploring or } \\
\text { addressing them in the AIP } \\
\text { development }\end{array}$ \\
\hline
\end{tabular}

Figure 3. EDUC 3007 Practitioner Inquiry 3: Applied Inquiry Plan.

\section{Fourth, we recognize and understand scholar} practitioner writing as a developmental process. The AIP provides a structure to recognize and accept the pressure to write within an honest, frank discussion that validates a person's anxieties and insecurities. Writing may not be effortless for many EdD students. We want students to accept the anxieties and insecurities with the goal to move beyond them to write to one's best ability and capacity and to see and understand the students' writing impacts for the benefit of stakeholders.

These discussions led to portraying scholarly practitioner writing as a professional responsibility, as part of students' progression from the practitioner to scholar practitioner as they create and implement practitioner inquiry agendas and write about their experience. Stakeholders need knowledge and direction on how to understand and lead change. While not the only vehicle to communicate with stakeholders, scholar practitioner professional writing is one that EdD programs can make explicit, promote and champion as a professional responsibility. Furthermore, that scholar practitioner writing is cumulative with a body of work (writing) created over time. Understanding writing as a developmental process does not lessen the work but rather provides structure and support, a pathway to create new knowledge and impact practice.

\section{Conclusion}

The AIP is to guide scholar practitioner inquiry reporting on systematic, data-driven (qualitative, quantitative, and mixed methods) efforts to improve the quality and value of practitioner scholar inquiry as well as to provide quality descriptions of the inquiry. The hope is the AIP challenges EdD students to write better and to think more clearly about the role of theory; interaction between context, interventions, and outcomes; and methods for studying improvement work.

EdD programs nurture and support students to write and document practice thereby creating new practice and knowledge to understand and lead change. Writing is an epistemological tool that EdD students can use to generate and disseminate their own practitioner inquiry agenda rooted in their practice and communities. Writing scaffolds such as the AIP provide opportunities for broad discussion of how to support and engage EdD students to view their writing as an epistemological tool. Looking forward a more concerted discussion linking the AIP elements with EdD programmatic outcomes is planned as a demonstration of the effectiveness of the AIP.

\section{ACKNOWLEDGMENT}

I want to recognize and thank my co-instructional team colleagues who teach with me using the AIP: Cindy Tananis, Jennifer Russell, Jill Perry, Kevin Crowley, Tom Akiva, Keith Trahan, and Sarah Capello.

\section{REFERENCES}

Bandura, A. (1995). Self efficacy in changing societies. Cambridge, UK: Cambridge University Press

Banks, W. \& Flinchbaugh, K. (2013) Experiencing ourselves as writers. In M. Eodice \& A. Geller (Eds.) Working with Faculty Writers (pp.228 - 245 ). Boulder, CO: Utah State University Press.

Bliss, J. \& Askew, M. (1996). Effective teaching and learning: Scaffolding revisited. Oxford Review of Education, 22 (1), 37-61.

Carnegie Project on the Education Doctorate. (2010). CPED design concepts. College Park, MD: Author.

Castells, M. (1996). The Rise of the network society: The information age: Economy, society, and culture, Volume I. Oxford, UK: Blackwell Publishers.

Goodman. D., Ogrinc, G., Davies, L., Baker, G., Barnsteiner, J., Foster, T., . .Thor, J. (2016). Explanation and elaboration of the SQUIRE (Standards for Quality Improvement Reporting Excellence) Guidelines, V.2.0: Examples of SQUIRE elements in the healthcare improvement literature. BMJ Quality and Safety, 25e (7). doi: 10.1136/bmjqs-2015-004480

Graff, G., \& Birkenstein, C. (2014). "They say/l say": The moves that matter in persuasive writing ( $3^{\text {rd }}$ Ed.). New York, NY: W.W. Norton \& Company.

Hoffmann, T., Glasziou, P., Boutron. I., Milne, R., Perera, R., Moher, D., . . Michie, S. (2014). Better reporting of interventions: template for intervention description and replication (TIDieR) checklist and guide. BMJ, Mar 7;348. doi: 10.1136/bmj.g1687

Hyland, K. (2004). Social interactions in academic writing. Ann Arbor, MI: University of Michigan Press.

Menter, I., Elliot, D. MHulme, M., Lewin, J., \& Lowden, K. (2011). A guide to practitioner research in education. Los Angeles, CA: Sage Publications.

Murphy, J., Berlin, J., Connors, R., Crowley, S., Enos, R., Vitanza, V., . Swearingen, J. (2009) The politics of historiography, Rhetoric Review, 7(1), 5-49. doi: 10.1080/07350198809388839 
Ogrinc, G., Mooney, S., Estrada. C., Foster. T., Goldmann, D., Hall, L.,...Watts, B. (2008). The SQUIRE (Standards for QUality Improvement Reporting Excellence) guidelines for quality improvement reporting: explanation and elaboration. Quality and Safe Health Care, 17. i13-i32, doi: 10.1136/qshc.2008.029058

Wolfberg, A. \& Lyytinen, K. (2017). Narrowing the dissemination gap: Genres for practitioner scholarship. Engaged Management ReView, 1(1) 1-17. doi: https://doi.org/10.28953/2375-8643.1034 